\author{
MaI VAN HaI \\ University of Łódź, Poland \\ Faculty of Economics and Sociology \\ 90-255 Łódź, 3/5 POW Street \\ Vietnam Academy of Social Sciences \\ Institute of Psychology \\ Ba Dinh District, Hanoi, Vietnam \\ 37 Kim Ma Thuong Street \\ e-mail: maivanhaipsy@gmail.com
}

\title{
GENDER EQUALITY IN FAMILY RELATIONS OF VIETNAMESE LIVING IN VIETNAM AND POLAND
}

\begin{abstract}
Gender equality is an important aspect of a happy family. It is expressed in equality of tasks sharing, decisions related to organization of family life, equal treatment of daughters and sons etc. The main aim of the study was to look at the effect of immigration on the perception of gender equality. Respondents of this study were 196 Vietnamese living in Vietnam (100 persons) and Poland (96 persons). Methods of the study included: the purposely designed questionnaire administered to all participants and the in-depth interview conducted with 15 Vietnamese who got married to Poles. Two types of family relations are the main focus of the paper: a relation between spouses and between parents and offspring. The results indicate equality of husbands and wives in work and economic aspects, as both work outside the house and contribute financially. Although participants overtly confirmed the equality of children of both sexes, but in particular situations they still expressed some preference for sons. Such pattern of results is confirmed in both groups of participants.
\end{abstract}

Keywords: equality, gender, immigrants, relations in family, gender equality, Vietnamese.

\section{INTRODUCTION}

Vietnamese society is a patriarchy. Therefore, a role of a man/father in a family is more important than a role of a woman (United Nations Population Fund, UNFPA, 2010). In a society influenced by Confucian ideology a woman must follow "Tam tòng": three major roles of a woman (a daughter to her parents, a wife to her husband and a widowed mother to her son) (Nguyen, 2014). The role of a woman in traditional Vietnamese families is not important. The husband or the first son (if the father died) has responsibility for organization, management and decision related to all issues in a family (Pham, 2004).

Preference for a son is an important feature of a patriarchal society. It is expressed in a desire to have at least one son to continue family lineage, worship 
ancestors (Belanger, 2002). It is believed that a son is more valuable than a daughter, as daughters must get married and live with a husband's family and therefore are considered to be outside their family line. That results in the inequality in treatment of sons and daughters: e.g. sons are more cared for and families invest more in their education (UNFPA, 2010). Reproductive technologies that enable parents to get information on sex of a fetus might prompt them to terminate a pregnancy if a fetus is of unwanted sex. Such selection in some countries results in the higher number of baby boys than baby girls (Townsend, 2007; Puri et al., 2011). The data provided by UNFPA (2010) indicate that the sex ratio in Vietnam is not balanced. In 2000, there were 106 boys for each 100 girls. In next years it was even worse: the ratio was 110 to 100 and 128 to 100 in 2008 and 2009, respectively.

Gender equality does not imply that women and men are the same, but that they have equal value and should be treated equally. The legal regulations in Vietnam protect gender equality. It is claimed that: "Women and men have the same role, position; the same condition and chance to prove their ability in contribution to the social development and the same rights for achievement" (Law of gender equality in Vietnam, 2006). Nowadays, the role and position of Vietnamese women are enhanced. They have many chances to enter the professional career and become successful in many occupations. Thus with the time passing the situation of Vietnamese women might become more similar to situation of women in Western societies.

Immigration gives an opportunity to observe other cultures and through the process of acculturation some of the customs and values typical for these cultures are absorbed (Wallas, 2010). Although gender equality is seriously considered in modern Vietnam, but contact through immigration with cultures such as European one, where gender equality is considered a significant value, might highlight this issue to a much greater extent and might significantly change the perspectives on gender equality. Therefore, it is interesting to investigate whether a prolonged contact with another culture changes the opinions on gender equality, especially the opinions of persons who originate from countries where traditionally gender equality was not executed and only recently - as in Vietnam - has received the legal support.

Although some aspects of social traditions make the Polish society a patriarchal one, but contrary to Vietnam the role of a woman, especially as a mother and a housekeeper, is very highly valued. For many years it were women who, as mothers bringing up their children, used to transfer important values and traditions to next generations. In the recent history of the country the issue of equal rights of women and men has received serious recognition and constitutional regulation. It is worth adding that voting rights - an important evidence of equality - were granted to Polish women much earlier than in some other European democracies. Changes observed recently in the Polish society include an increased partnership in marriage and family as well as men's involvement in childcare. Dual-career couples are becoming more and more popular and situation when women achieve professionally more than their partners is not exceptional 
(Janicka, Liberska, 2014). Nevertheless there is still a strong debate whether the Polish society protects sufficiently equal rights of men and women and gender equality (Budorowska, 2000; Morawiecka, 2011; Sikorska, 1996; Titkow, Domański, 1995). It seems very likely that the social debate on women rights in Poland and the way such rights are executed is different from the situation in Vietnam. Thus immigrants are confronted with different approach to certain aspects of social life.

It is estimated that Vietnamese community in Poland reaches up to 300050000 people (Report of Vietnamese Ambassador about Vietnamese People in Poland, 2013; Szymańska, 2015), who are mostly involved in business in commercial centers or work as cooks in restaurants. The economic reasons for immigration were already confirmed (Boski, 2013; Szymańska, 2015). Although the studies into the acculturation of immigrants have been conducted (van de Vijver, 2007; Rodher, Muhlau, 2014) and some of them investigated the effects of immigration with Vietnamese samples looking at their approach to family life and family values (Rosenthal et al., 1996), such studies - to the author's knowledge - were not conducted with Vietnamese living in Poland. Similarly, little is known about their opinions on gender equality, especially in comparison with opinions pertaining in modern Vietnam. Thus the research project was designed to investigate how the process of acculturation affects the Vietnamese community in the country such as Poland. It is particularly interesting whether and how the life style and traditional family values, as well as the approach to gender equality, might have changed as the effect of close contact with the Polish society. In this paper only part of the research results is presented, i.e. the one related to gender equality.

\section{METHOD}

The data presented in the paper are part of a larger study that investigated family values of Vietnamese living in Vietnam and in Poland by means of questionnaire and in-depth interview. None of previously constructed questionnaires addresses issues related to family values and gender equality and is validated for Vietnamese population, including Vietnamese immigrants in Poland. Similarly, the author is not familiar with any relevant interview scenario. Therefore it was decided to design the tools for the purpose of the study.

\subsection{Questionnaire}

The questionnaire used in the study includes open questions that allow participants to elaborate their answers as well as questions where an answer can be selected from the options provided. It gives scores for individual items and the combined scores. 
The questionnaire has 12 parts. Part 1 lists general values based on studies by Hac (2010) and Schwartz (1996, 2012), Part 2 and 3 refer to two basic relations in a family-relation of husband and wife and relation of parents and offspring, while part 9 to the preference of a son. All these include items that require answers/ opinions on a 5-point scale, from 1 "strongly disagree" to 5 "strongly agree". Participants report on their level of agreement with a particular item and predict the level of other people's agreement. While giving answers/opinions participants consider two different aspects: beliefs and behavior. Most of the items in this part are related to traditional family values.

Parts $4,5,6,7,8,10,11,12$ are open questions that are related to family values of Vietnamese participants in different contexts.

The questionnaire was originally developed in English and translated into Vietnamese and then piloted. The results of the pilot survey indicated that some items should be rephrased. Questionnaire in Vietnamese language was administered both in Vietnam and in Poland.

\subsection{Interview}

The in-depth interview was designed to collect data on some sensitive issues such as: adultery, preference of a son, and to give participants the opportunity to elaborate on their experiences of being immigrants, on their adjustment to a different society and on their efforts to preserve traditional Vietnamese culture and values.

Interviewed participants were recruited through the "snow-ball" method. After each interview the researcher asked participants to introduce him to other Vietnamese persons who got married to Poles. The decision to conduct interviews with such a group was based on the assumption that persons in mixed marriages have different opportunities for acculturation and can provide deeper insight into issues related to immigration and life in a foreign country. Most of the interviews were conducted in Poland.

Each in-depth interview lasted about 1 hour and took place in a respondent's home, office, or in other places where participants felt safe to share their opinions. The interviews were tape-recorded and then transcribed. There were 2 respondents who didn't agree to record the interview, thus the researcher made notes during the interview and immediately after it. Initially the interview had 11 questions. Then, after the pilot survey (with 1 person in Warsaw and 2 persons in Lodz), it was decided to add 2 questions about preference of a son and the reasons of adultery among Vietnamese living in Poland. The order of questions was flexible and depended on the rapport of interviewer and participant. 


\subsection{Participants}

The sample consists of 196 Vietnamese respondents: 100 people living in Vietnam and 96 people living in Poland for more than 3 years. All these persons-after giving the informed consent-filled-in the questionnaire described above.

The in-depth interview was conducted with 15 respondents who got married to Poles. These persons belonged both to the group of Vietnamese living in Poland and in Vietnam, but they were not filling-in the questionnaire.

\subsection{Analyses}

All analyses were conducted with SPSS package (PS Imago, version 18). Mean scores and standard deviations were computed and $t$-test for independent samples was used for comparison of groups, with $\mathrm{p}<0,05$ considered significant.

\section{RESULTS}

Findings presented in this section are based on data from different parts of the questionnaire and from the interview. Gender equality is analyzed here with the focus on relations between spouses and on attitudes to sons and daughters.

\subsection{Gender equality in husband-wife relations}

Table 1 gives mean scores on selected items of the questionnaire for both groups of participants. The items are related to rights and equality of the spouses and some of them - like item 8 - are based on traditional Vietnamese proverbs.

Table 1. Relations within a couple - economic aspects (item 1-3), mutual relations (item 4-8) and ways to express partners' equality (item 9-12) - mean scores (standard deviation) and $p$ values (comparison with $t$-test for independent samples)

\begin{tabular}{|c|c|c|c|c|}
\hline & Items & $\begin{array}{l}\text { Participants } \\
\text { living }\end{array}$ & $\begin{array}{c}\text { Participants } \\
\text { living in Poland }\end{array}$ & $\mathrm{p}$ \\
\hline & 1 & 2 & 3 & 4 \\
\hline 1 & $\begin{array}{l}\text { In the couple partners cannot have their own } \\
\text { property, private funds - all should belong to } \\
\text { both of them }\end{array}$ & $\begin{array}{c}3,07 \\
(1,10)\end{array}$ & $\begin{array}{c}3,76 \\
(1,02)\end{array}$ & 0,001 \\
\hline 2 & $\begin{array}{l}\text { Spouses have always to support each other. } \\
\text { Property, money in the family belongs to } \\
\text { both of them }\end{array}$ & $\begin{array}{c}4,08 \\
(0,73)\end{array}$ & $\begin{array}{c}4,29 \\
(0,74)\end{array}$ & 0,044 \\
\hline
\end{tabular}


Table 1.cont.

\begin{tabular}{|c|l|c|c|c|}
\hline \multicolumn{1}{|c|}{1} & 2 & 3 & 4 \\
\hline \multirow{2}{*}{3} & $\begin{array}{l}\text { Wealth, success of a husband is shared? by } \\
\text { his wife }\end{array}$ & $\begin{array}{c}3,69 \\
(0,90)\end{array}$ & $\begin{array}{c}3,93 \\
(0,96)\end{array}$ & 0,067 \\
\hline \multirow{2}{*}{4} & $\begin{array}{l}\text { When a husband is angry, a wife should keep } \\
\text { calm }\end{array}$ & $\begin{array}{c}4,09 \\
(0,72)\end{array}$ & $\begin{array}{c}4,38 \\
(0,72)\end{array}$ & 0,006 \\
\hline \multirow{2}{*}{5} & $\begin{array}{l}\text { When a husband is ill-tempered, a wife } \\
\text { should give way and step aside }\end{array}$ & $\begin{array}{c}3,78 \\
(0,84)\end{array}$ & $\begin{array}{c}3,97 \\
(0,86)\end{array}$ & 0,117 \\
\hline \multirow{2}{*}{6} & $\begin{array}{l}\text { A husband can have many wives, good wife } \\
\text { does not marry twice }\end{array}$ & $\begin{array}{c}1,92 \\
(1,10)\end{array}$ & $\begin{array}{c}1,94 \\
(1,13)\end{array}$ & 0,865 \\
\hline \multirow{2}{*}{7} & $\begin{array}{l}\text { If a wife has a bad husband, she should } \\
\text { peacefully accept her fate }\end{array}$ & $\begin{array}{c}1,81 \\
(0,96)\end{array}$ & $\begin{array}{c}1,96 \\
(0,95)\end{array}$ & 0,249 \\
\hline \multirow{2}{*}{8} & $\begin{array}{l}\text { When spouses agree with each other, they } \\
\text { can dry up the ocean with buckets }\end{array}$ & $\begin{array}{c}4,30 \\
(0,79)\end{array}$ & $\begin{array}{c}4,55 \\
(0,64)\end{array}$ & 0,014 \\
\hline \multirow{2}{*}{9} & $\begin{array}{l}\text { Equal rights to decide on important issue in } \\
\text { family }\end{array}$ & $\begin{array}{c}4,15 \\
(0,70)\end{array}$ & $\begin{array}{c}4,36 \\
(0,78)\end{array}$ & 0,701 \\
\hline \multirow{2}{*}{10} & $\begin{array}{l}\text { Equal rights to make money and decide on } \\
\text { spending money }\end{array}$ & $\begin{array}{c}3,73 \\
(0,86)\end{array}$ & $\begin{array}{c}4,02 \\
(0,88)\end{array}$ & 0,862 \\
\hline \multirow{2}{*}{11} & $\begin{array}{l}\text { Equal responsibility for organization and } \\
\text { administration of all activities in family }\end{array}$ & $\begin{array}{c}4,02 \\
(0,69)\end{array}$ & $\begin{array}{c}4,11 \\
(0,79)\end{array}$ & 0,696 \\
\hline \multirow{2}{*}{12} & $\begin{array}{l}\text { Cooking, cleaning, childcare... are } \\
\text { responsibility of both spouses }\end{array}$ & $\begin{array}{c}4,11 \\
(0,72)\end{array}$ & $\begin{array}{c}3,98 \\
(0,85)\end{array}$ & 0,723 \\
\hline
\end{tabular}

Items presented in table 1 have been scored differently, which reflects that some aspects of relations were more important (higher score) than others (lower score). In that perspective issues of equality of spouses' obligations to their family and to each other can be considered very important. However, only a few items were scored significantly different by two groups. In all such cases Vietnamese living in Poland gave higher scores than those living in Vietnam, which reflected their stronger agreement with the content of the item. The pattern of significant differences is puzzling as Vietnamese living in Poland scored higher on items reflecting equality of spouses (item 1 and 2) and at the same time on items reflecting traditional female roles (item 4 and 8 ).

\subsection{Gender equality expressed in attitude towards sons and daughters}

Gender equality in parents - offspring relations is presented most clearly through an attitude towards sons and daughters. Such attitude is a sensitive issue; it is embedded in historical tradition and is expressed subtly in everyday life. Table 2 presents data on beliefs and behaviors related to equality of sons and daughters in the two groups of respondents. 
Table 2. Preference for sons as reflected in opinions (item 1-12) and in preferred behaviour (item 13-20) - mean scores (standard deviation) and $p$ values (comparison with $t$-test for independent samples)

\begin{tabular}{|c|c|c|c|c|}
\hline & Items & $\begin{array}{l}\text { Participants } \\
\text { living } \\
\text { in Vietnam }\end{array}$ & $\begin{array}{c}\text { Participants } \\
\text { living in Poland }\end{array}$ & $\mathrm{p}$ \\
\hline 1 & $\begin{array}{l}\text { Family must have at least one son to continue } \\
\text { family line/lineage }\end{array}$ & $\begin{array}{c}2,75 \\
(1,05)\end{array}$ & $\begin{array}{c}2,86 \\
(1,14)\end{array}$ & 0,474 \\
\hline 2 & $\begin{array}{l}\text { Daughter-in-law must live in house of } \\
\text { husband family }\end{array}$ & $\begin{array}{c}2,70 \\
(0,97)\end{array}$ & $\begin{array}{c}2,66 \\
(1,03) \\
\end{array}$ & 0,799 \\
\hline 3 & $\begin{array}{l}\text { Fortune of parents will be inherited mostly } \\
\text { by their sons }\end{array}$ & $\begin{array}{c}2,60 \\
(1,03)\end{array}$ & $\begin{array}{c}2,43 \\
(0,93)\end{array}$ & 0,234 \\
\hline 4 & $\begin{array}{l}\text { Parents and family members arrange the } \\
\text { marriage for offspring }\end{array}$ & $\begin{array}{c}1,79 \\
(0,83)\end{array}$ & $\begin{array}{l}1,56 \\
.83\end{array}$ & 0,094 \\
\hline 5 & $\begin{array}{l}\text { Women when getting married must be } \\
\text { dependent on their husband }\end{array}$ & $\begin{array}{c}2,39 \\
(1,00)\end{array}$ & $\begin{array}{c}2,10 \\
(0,88)\end{array}$ & 0,037 \\
\hline 6 & $\begin{array}{l}\text { Duty of a daughter-in-law is to continue } \\
\text { family line by giving birth/bearing children }\end{array}$ & $\begin{array}{c}2,91 \\
(1,11)\end{array}$ & $\begin{array}{c}2,68 \\
(1,16) \\
\end{array}$ & 0,153 \\
\hline 7 & $\begin{array}{l}\text { Only the son maintains kinship, the daughter } \\
\text { is outside of a family lineage }\end{array}$ & $\begin{array}{c}2,32 \\
(1,11)\end{array}$ & $\begin{array}{c}2,30 \\
(1,08)\end{array}$ & 0,926 \\
\hline 8 & $\begin{array}{l}\text { Daughter-in-law always has to focus on } \\
\text { taking care of husbands' parents }\end{array}$ & $\begin{array}{c}2,88 \\
(1,01) \\
\end{array}$ & $\begin{array}{c}2,70 \\
(1,04)\end{array}$ & 0,237 \\
\hline 9 & $\begin{array}{l}\text { Daughter or son, daughter-in-law or son-in- } \\
\text { law are also the offspring, and as such should } \\
\text { be treated equally }\end{array}$ & $\begin{array}{l}4,26 \\
(0,82)\end{array}$ & $\begin{array}{l}4,35 \\
(0,83)\end{array}$ & 0,462 \\
\hline 10 & The son always worships ancestors & $\begin{array}{c}3,46 \\
(1,05)\end{array}$ & $\begin{array}{c}3,59 \\
(1,09) \\
\end{array}$ & 0,398 \\
\hline 11 & If a man hasn't got a son, he is worthless & $\begin{array}{c}2,21 \\
(1,13) \\
\end{array}$ & $\begin{array}{c}2,11 \\
(1,10) \\
\end{array}$ & 0,558 \\
\hline 12 & $\begin{array}{l}\text { When becoming older, parents rely on their } \\
\text { sons }\end{array}$ & $\begin{array}{c}3,71 \\
(0,90)\end{array}$ & $\begin{array}{c}3,53 \\
(1,00)\end{array}$ & 0,207 \\
\hline 13 & Trying to have at least one son & $\begin{array}{c}2,75 \\
(1,05)\end{array}$ & $\begin{array}{c}2,88 \\
(1,10)\end{array}$ & 0,415 \\
\hline 14 & $\begin{array}{l}\text { Taking care of husbands' parents (a duty of } \\
\text { a daughter-in-law) }\end{array}$ & $\begin{array}{c}3,73 \\
(0,89)\end{array}$ & $\begin{array}{c}3,62 \\
(0,88)\end{array}$ & 0,427 \\
\hline 15 & My son will inherit most of my fortune & $\begin{array}{c}2,83 \\
(0,94)\end{array}$ & $\begin{array}{c}2,57 \\
(0,98)\end{array}$ & 0,062 \\
\hline 16 & $\begin{array}{l}\text { Women's marriage should be based on } \\
\text { arrangement by their parents }\end{array}$ & $\begin{array}{c}1,93 \\
(0,83)\end{array}$ & $\begin{array}{c}1,64 \\
(0,84)\end{array}$ & 0,015 \\
\hline 17 & $\begin{array}{l}\text { Taking care of sons (in education, health } \\
\text { care) more than of daughters }\end{array}$ & $\begin{array}{c}1,91 \\
(0,82)\end{array}$ & $\begin{array}{c}1,82 \\
(0,92)\end{array}$ & 0,436 \\
\hline 18 & Treating equally the son and the daughter & $\begin{array}{c}4,27 \\
(0,86)\end{array}$ & $\begin{array}{c}4,45 \\
(0,83) \\
\end{array}$ & 0,134 \\
\hline 19 & Worshiping ancestors (if you are the son) & $\begin{array}{c}4,04 \\
(0,92) \\
\end{array}$ & $\begin{array}{c}4,03 \\
(0,99) \\
\end{array}$ & 0,941 \\
\hline 20 & $\begin{array}{l}\text { Applying some ways and methods to choose } \\
\text { the sex of a fetus }\end{array}$ & $\begin{array}{c}2,38 \\
(1,02)\end{array}$ & $\begin{array}{c}2,15 \\
(1,02)\end{array}$ & 0,132 \\
\hline
\end{tabular}


The results given in table 2 indicate that items expressing gender equality have the highest scores both in belief (item 9) and in behavior (item 18) aspects. This result indicates that besides the preference for sons (discussed in more details below), participants implement the idea of equality of their children. Views related to gender equality are stronger, although not significantly, among those living in Poland.

Although daughters can conduct worship ancestor ceremony in Vietnamese society nowadays, mostly if a family has no son, this duty is traditionally performed by sons, especially the first-born/oldest son. Scores in table 2 reflect these traditional preferences. For some of the items presented in table 2 participants living in Vietnam gave higher (however not significantly different) scores then those living in Poland. These items reflect the idea that a son is more valuable than a daughter. Thus the preference for sons in Vietnamese living in Vietnam might be stronger than in Vietnamese living in Poland.

Scores for two items (5 and 16) are significantly different for the two groups, and are related to the situation of women who while married are dependent on their husband and his parents. Such beliefs are more common and stronger among Vietnamese living in Vietnam than in those living in Poland.

Social context can help to understand why in some items participants living in Vietnam have higher scores than those in Poland, i.e. item 20 (the choice of sex of a fetus), item 12 (relying on their sons when getting older). In Vietnam, fetal sex selection still exists and social welfare is not good, thus elders must rely on their offspring.

\subsection{Gender equality as described in in-depth interviews}

Findings form interviews showed that while discussing gender equality participants expressed 2 types of opinions. The first trend is presented by a group of people who think that daughters and sons are equal. They even like daughters more than sons. This trend was presented by a smaller number of participants. Below there are some typical comments. What is more, these comments clearly indicate the impact of the Polish culture:

Vietnamese custom is to have at least one son to maintain the continuity of a family line. In here, son and daughter are equal. The daughter even takes care of parents more than the son. Having a son is not important to me. Europeans even like daughters more than they like sons (Ng. C, male, Lodz).

I don't want to have at least one son. Even, I like a daughter more than a son. The daughter is often closer with a mother than the son (Th. H, female, Warsaw).

As I think, everybody in Vietnam likes having a son. If my husband were Vietnamese, we would have the son. But my husband is Polish. Polish people treat daughters and sons in the same way. I think both a daughter and a son are offspring although Vietnamese still show preference for a son (N.T.K.K, female, Warsaw). 
Below there are some opposite opinions which confirm that a son is still more valuable than a daughter.

I'm Vietnamese, I have lived abroad for 30 years, but I'm still a Vietnamese. This is continuity of a family. I have the son and the grandson in Vietnam. My grandson is intelligent, healthy. So, I don't worry about anything (P.V.D, male, Lodz).

I think I must have at least one son. Whether my son is here or in Vietnam is not important. But I must have a son (H.V.N, male, Lodz).

Yes, I want a son. I don't want a daughter because I don't want her to be as miserable as me (H, female, Lodz).

These excerpts confirm the existing preference for sons in Vietnamese living in Poland and its link to traditional cultural beliefs and values. To some extent these comments depict the position of women in Vietnamese society.

People who confirmed the gender equality and equal preferences for sons and daughters were more often fully integrated with the Polish society (i.e. they spoke Polish fluently, lived in Poland for a long time, their children were born and lived in Poland). On the other hand Vietnamese participants living in Poland might try to retain their cultural identity more than those living in Vietnam. Preference for a son is deeply embedded in Vietnamese beliefs and customs. Therefore those living in Poland might still vividly express these traditional beliefs despite the long period of time spent abroad.

\section{DISCUSSION}

Gender equality was studied extensively by many disciplines due to its important role in people's life. The examples of its importance are recent analyses of its role in a workplace (Wu, Cheng, 2016) and the need for its proper indices in cross-cultural studies (Senem, 2016). The idea of gender equality leads to unprejudiced views on males and females and their role in the society. To some extent it might prevent the sex imbalance observed in birth rate reflected in demographic data for some countries, including Vietnam. Gender equality is also an important element of family life and family values. The approach to gender equality was studied among immigrants, including such aspect as fetal sex selection (e.g. Puri et al., 2011), availability of education and work prospects (e.g. Rosenthal et al., 1996). These studies demonstrated the immigrants' gender bias in child's education, occupation, as well as in fetal sex selection. Results of these studies indicate as well that focus on gender equality would provide an important contribution to the knowledge on immigrants' opinions and beliefs and would provide insight into the process of acculturation. 
The results presented in the paper showed that Vietnamese respondents expressed quite clearly their positive views on gender equality in issues related to work, family life, rights and obligations of men and women. Not all aspects of gender equality are important to the same extent, which is reflected in higher scores for some of them and lower scores for others. The differences in findings for respondents living in Poland and respondents in Vietnam were mostly not significant. That might reflect the fact that immigrants are still attached to the traditions of their country of origin and as such express similar views as those living in Vietnam. On the other hand, Vietnamese living in Vietnam present positive approach to some aspects of gender equality, which might reflect the effects of recent legal regulation or some ongoing social changes in Vietnam. Relatives and friends who live outside Vietnam might be the source of information on other societies and examples of different lifestyle, thus contacts with them might influence the opinions and attitudes of those who live in Vietnam. Thus one can think of a twoway relationship. On one hand, traditional values of a home country affect immigrants who try to preserve them and adjust to them while on immigration. On the other hand, rules and customs of a country of immigration through changes in immigrants' lifestyle might affect the society in a country of origin. It can't be concluded that the second mechanism is reflected in the data presented above, mostly due to the cross-sectional character of the study. However, it is not possible to rule it out entirely as Vietnamese immigrants in Poland maintain close contacts with their home country.

The process of acculturation and adaptation of immigrants who live in Poland should be considered, as their views were less related to traditional Vietnamese beliefs and customs when compared to views of Vietnamese living in Vietnam. One example might be the wish to have a son. Asian in general and Vietnamese in particular often express the desire to have a son. Such desire has its origins in culture, social opinions, and also in economics. Results of the present study confirmed the existence of such preference, though it was not strongly expressed and often criticized by those who lived in Poland for a longer period of time. Through such opinions one can see the effects of contacts with another culture where sex of a child is less important or has become less important with time.

The present study has some limitations. Firstly, it is based on a relatively small sample which was not randomized. Secondly, it includes participants in a good socioeconomic situation, mostly middle class from big cities, who might be more kin to accept new trends in social life, including gender equality. Thirdly, it includes participants of a relatively young age, who might accept gender equality more than older generation. Although the study was purposely designed to be conducted with Vietnamese immigrants in Poland, but the research conducted in many more countries and with larger samples would supply more knowledge on this interesting issue related to Vietnamese immigrants. 


\section{REFERENCES}

Belanger D. (2002). Son preference in rural village in North Vietnam. Studies in Family Planning, 33 (4), 321-334.

Boski P. (2013). A psychology of economic migration. Journal of Cross-Cultural Psychology, 44 (7), 1067-1093.

Budorowska B. (2000). Macierzyństwo jako punkt zwrotny w życiu kobiety. Wrocław: Wydawnictwo Funna.

Hac P. M. (2010). Axiology, theoretical foundation contributes to general values of Vietnamese nowadays, Hanoi: Education Publishing House.

Janicka I., Liberska H. (ed.) (2014). Psychologia rodziny. Warszawa: Wydawnictwo Naukowe PWN.

Law of gender equality in Vietnam (2006). http://moj.gov.vn/vbpq/lists/vn\%20bn\%20php\%20lut/ view_detail. aspx?itemid=14854 [accessed: 1.06.2016].

Morawiecka E. (2011). Pożegnanie Matki Polki - nowy obraz psychospołeczny kobiet w Polsce. Przegląd badań aktywności zawodowej i rodzinnej kobiet. [W:] B. Bartosz (red.), Wymiary kobiecości i męskości. Od psychobiologii do kultury (s. 259-273). Warszawa: ENETEIA Wydawnictwo Psychologii i Kultury.

Nguyen T. V. (2014). Three subjections of woman and Four virtues in Confucianism and its influence to Vietnamese woman nowadays, Dissertation, Ho Chi Minh National Academy of Politics and Public Administration.

Pham V. L. (2004). Proverb and folk song and family relation. Hanoi: National Political Publishing House.

Puri S., Adams V., Ivey S., Nachtigall R. D. (2011). There is such a thing as too many daughters, but not too many sons": A qualitative study of son preference and fetal sex selection among Indian immigrants in the United States. Social Science and Medicine, 72 (7), 1169-1176.

Report of Vietnamese ambassador about Vietnamese people in Poland (2013). Unpublished manuscript.

Rodher A. Muhlau P. (2014). Are they acculturating? Europe's immigrants and gender egalitarianism. Social Forces, 92 (3), 899-928.

Rosenthal D., Ranieri N., Klimidis S. (1996). Vietnamese adolescents in Australia: relationships between perceptions of self and parental values, intergenerational conflict, and gender dissatisfaction. International Journal of Psychology, 31 (2), 81-91.

Schwartz S. H. (1996). Value priorities and behavior: Applying a theory of integrated value system. London: Lawrence Erlbaum.

Schwartz S. H. (2012). An Overview of the Schwartz Theory of Basic Values. Online Readings in Psychology and Culture. International Association for Cross-Cultural Psychology.

Senem E. (2016). How to study gender equality policy cross-nationally? Aggregate or disaggregate gender equality policy indices? Social Indicators Research, 125 (1), 15-20.

Sikorska J. (red.) (1996). Kobiety i ich mężowie. Studium porównawcze. Warszawa: Wydawnictwo IFiS PAN.

Szymańska G. (2015).The Vietnamese communities in Central and Eastern Europe as Part of the Global Vietnamese diaspora, http://www.ceemr.uw.edu.pl/vol-4-no-1-june-2015/editorial/ vietnamese-communities-central-and-eastern-europe-part-global [accessed: 1.06.2016].

Titkow A., Domański H. (red. (1995). Co to znaczy być kobieta w Polsce. Warszawa: Wydawnictwo IFiS PAN.

Townsend L. (2007). Vietnam facing dangerous gender imbalance. National Right to Life News, December, 23-27.

Van de Vijver F. J. R. (2007). Cultural and gender differences in gender-role beliefs, sharing household task and child-care responsibilities, and well-being among immigrants and majority members in the Netherlands. Journal of Sex Roles, 57 (4), 813-824. 
United Nations Population Fund (UNFPA) (2010). When girls don't count as much as boys. Prenatal sex selection in Viet Nam. http://www.unfpa.org/news/when-girls-don\%E2\%80\%99t-count-much-boys-pre-natal-sex-selection-viet-nam [accessed: 1.06.2016].

Wallas M. (2010). Lęk akulturacyjny cudzoziemców w aspekcie tożsamości i procesów integracyjnych w nowym kraju pobytu. Środkowoeuropejskie Studia Polityczne, 4, 75-87.

Wu R., Cheng X. (2016). Gender equality in the workplace: the effect of gender equality on productivity growth among the Chilean manufacturers. The Journal of Developing Areas, 50 (1), 23-28.

\author{
MAI VAN HAI
}

\title{
RÓWNOŚĆ PLCI W RELACJACH RODZINNYCH WIETNAMCZYKÓW MIESZKAJĄCYCH W WIETNAMIE I W POLSCE
}

\begin{abstract}
Abstrakt. Równość płci jest ważnym aspektem dobrego funkcjonowania rodziny. Wyraża się w równości w zakresie podziału obowiązków, podejmowania decyzji związanych z organizacją życia rodzinnego, równego traktowania synów i córek itp. Celem badania była ocena, w jakim stopniu imigracja modyfikuje spostrzeganie równości płci w rodzinie. W badaniu uczestniczyło 196 osób (100 Wietnamczyków mieszkających w Wietnamie i 96 mieszkających w Polsce), które wypełniały kwestionariusz opracowany na potrzeby badania. Dodatkowo 15 osób, które zawarły związki małżeńskie z Polakami, uczestniczyło w pogłębionym wywiadzie. Analizowano dwa typy relacji rodzinnych: pomiędzy małżonkami oraz pomiędzy rodzicami i dziećmi. Uzyskane rezultaty wskazują na akceptowanie równości kobiet i mężczyzn pod względem ekonomicznym, skoro oboje partnerzy pracują poza domem oraz zarabiają pieniądze. Choć badani otwarcie akceptowali równość synów i córek, to w szczególnych sytuacjach wyrażali wolę posiadania syna. Obie grupy Wietnamczyków - mieszkających w Wietnamie i w Polsce - wykazały wiele podobieństw w zakresie swoich poglądów dotyczących równości płci.
\end{abstract}

Słowa kluczowe: równość, płeć społeczna, imigranci, relacje w rodzinie, równość płci, Wietnamczycy. 